\title{
PERANAN ATRIBUT EKSTRINSIK MEREK TERHADAP MINAT BELI KONSUMEN SMARTPHONE BLACKBERRY
}

\author{
Anas Hidayat \\ Anas.hidayat@uii.ac.id \\ Fakultas Ekonomi Universitas Islam Indonesia \\ Lhia Dwi Agustina \\ Ihialhiar@yahoo.com \\ Fakultas Ekonomi Universitas Islam Indonesia
}

\begin{abstract}
This research aims to examine the role of brand preference, luxury brand perception and country of origin in influencing consumers to buy Blackberry smarthphone, as well as to examine the role of country of origin in influencing luxury brand perception. The population of this research are students in economics faculty of Indonesia Islamic University, and the sample used is 250 respondent. This research was found that the most devotee of blackberry smartphone is women, with $53,6 \%$, aged between 18-23 years old, with a pocket money between Rp1.000.000-Rp2.000.000 monthly and expenditure of Rp500.000-Rp1.499.999 monthly. By using Structural Equation Modeling, the results show that there are positive and significant impact on the country of origin to the purchase intention, positive and significant impact on the country of origin to luxury brand perception, positive and significant impact on the luxury brand perception to purchase intention and positive and significant impact on the brand preference to purchase intention of blackberry smartphone's consumer in economics faculty of Indonesia Islamic University.
\end{abstract}

Keywords: brand preference, luxury brand perception, country of origin, purchase intention

\section{PENDAHULUAN}

Era globalisasi telah memberikan perubahan yang sangat besar bagi dunia perekonomian termasuk dengan Indonesia, Seiring dengan era globalisasi ini terjadi perkembangan teknologi yang semakin hari semakin canggih, hal ini menjanjikan suatu peluang dan tantangan bagi perusahaan untuk menciptakan teknologi canggih yang mampu memenuhi kebutuhan konsumen. Dengan perkembangan ini pula, dapat menimbulkan persaingan antara pelaku bisnis dibidang teknologi khususnya alat komunikasi berupa telepon genggam. 
Telepon genggam awalnya diciptakan untuk memenuhi kebutuhan komunikasi konsumen. Namun, seiring perkembangannya telepon genggam bukan hanya sekedar untuk memenuhi kebutuhan komunikasi dari konsumennya saja, akan tetapi juga memberikan fungsi tambahan sebagai sarana hiburan bagi pemakainya. Pada perkembangannya, lahirlah smartphone yang diyakini sebagai generasi terakhir dari telepon genggam pada saat ini. Smartphone lahir bukan hanya sebagai sebuah alat komunikasi, akan tetapi smartphone diproduksi dengan beberapa fungsi sebagai hiburan, akses nirkabel dan akhirnya menjadi bagian dari lifestyle pemiliknya. Blackberry adalah salah satu merek Smartphone yang digemari di beberapa negara termasuk Indonesia, saat ini pengguna smartphone dengan merek Blackberry di Indonesia telah mencapai lebih dari 15 juta pengguna per juni 2013 (www.chip.co.id). Dengan strategi pemasaran membangun komunitas pengguna yang dilakukan oleh operator layanan Blackberry, semakin menguatkan posisi smartphone Blackberry sebagai bagian dari lifestyle pemiliknya.

Produsen dari smartphone dituntut untuk lebih memahami kebutuhan dan keinginan dari konsumennya, serta motivasi apa saja yang mendasari perilaku konsumen. Hal ini akan mendasari para pemasar untuk memahami dan meramalkan perilaku konsumen. Perilaku konsumen merupakan suatu proses yang muncul saat individu memilih, menggunakan dan membuang produk ataupun jasa untuk memenuhi kebutuhan dan keinginanya (Kristina, 2013). Minat beli merupakan bagian dari perilaku konsumen dalam mengkonsumsi dan bertindak sebelum benar-benar melakukan keputusan pembelian. Menurut Ghalandari dan Norouzi (2012) minat beli adalah probabilitas pelanggan dalam situasi tertentu saat memilih merek tertentu dari sebuah kategori produk.

Dari penelitian yang dilakukan oleh Rouhani dan Hanzaee (2011), terdapat beberapa prediktor atau variabel yang mempengaruhi minat beli konsumen, diantaranya country of origin (negara asal), luxury brand perception (persepsi merek mewah), brand preference (peferensi merek) dan brand familiarity. Dalam penelitian ini, tidak dicantumkan variabel brand familiarity, meskipun variabel ini memiliki pengaruh terhadap minat beli konsumen, akan tetapi brand familiarity belum tentu untuk meningkatkan minat beli konsumen pada smartphone Blackberry. Selain itu, brand familiarity adalah variabel dinamis, artinya variabel yang dapat diubah keberadaannya berupa pengubahan, peningkatan atau penurunan (Arikunto, 2002).

Penelitian selanjutnya yang dilakukan oleh Kristina (2013), yang meneliti pengaruh country of origin, luxury brand perception, dan brand preference terhadap minat beli mobil Honda Jazz, ditemukan bahwa ketiga prediktor/ variabelnya memiliki pengaruh positif dan signifikan terhadap minat beli konsumen. Country of origin (COO) adalah persepsi umum konsumen akan suatu kualitas produk yang dibuat oleh suatu negara (Bilkey dan Nes dalam 
Susanti dan Dwi, 2010). Para konsumen mengevaluasi sebuah produk tidak hanya melalui penampilan dan karakteristik-karakteristik saja, tetapi juga negara asal dimana produk tersebut dibuat.

Prediktor kedua yang mempengaruhi minat beli konsumen adalah luxury brand perception atau persepsi merek mewah. Menurut Rouhani dan Hanzaee (2011), untuk barang-barang mewah, COO cenderung memiliki efek yang lebih kuat daripada harga dalam penilaian kualitas produk. Lebih jauh peneliti ini juga mengatakan bahwa produk mewah adalah tanda status dan kelas dalam masyarakat modern. Bahkan mereka mengatakan bahwa COO akan lebih mempengaruhi keputusan beli konsumen ketika membeli merek mewah.

Selain negara asal dan persepsimerek mewah, prekditoryang mempengaruhi minat beli konsumen adalah brand preference atau preferensi merek. Menurut Kristina (2013) preferensi merek adalah keadaan dimana konsumen menyukai merek karena merek tersebut membanggakan. Oleh karena itu, kegiatan membangun citra suatu merek sangat perlu untuk dikembangkan oleh pemasar atau perusahaan, sehingga konsumen akan menyukai merek dari produk yang kita buat. Penelitian Kristina (2013) serta Rouhani dan Hanzaee (2011) menunjukkan bahwa preferensi merek memiliki pengaruh positif dan signifikan terhadap minat beli konsumen terhadap suatu produk, artinya semakin tinggi seseorang menyukai suatu merek maka semakin tinggi pula minat belinya.

Penelitian ini akan difokuskan pada usaha untuk mengungkap pengaruh positif brand preference, luxury brand perception dan country of origin terhadap minat beli konsumen smartphone Blackberry serta pengaruh positif antara country of origin terhadap luxury brand perception. Melalui penelitian ini diharapkan dapat memberikan gambaran yang jelas mengenai sejauh mana sikap konsumen terhadap produk smartphone Blackberry, terutama di kalangan anak muda yang sedang menjalankan pendidikan S1. Selanjutnya dapat dipakai sebagai bahan pertimbangan untuk menetapkan strategi pemasaran selanjutnya bagi perusahaan yang bersangkutan.

\section{KAJIAN PUSTAKA}

Bagian ini akan mengkaji tentang beberapa faktor yang mempengaruhi minat beli konsumen terhadap suatu produk. Kajian pustaka ini dimaksudkan untuk mendokumentasikan dan mengkaji berbagai teori, konsep, anggapan dasar serta hubungan antara berbagai variabel yang digunakan untuk pemecahan masalah.

\section{Minat Beli}

Ketika konsumen akan melakukan pembelian suatu produk, konsumen terlebih dahulu akan mencari dan mengumpulkan informasi berdasarkan pengalaman pribadi atau melalui lingkungan eksternal. Hal inilah yang dipertimbangkan oleh konsumen sebelum benar-benar melakukan pembelian. 
Ketika jumlah informasi itu dirasa cukup oleh konsumen dalam proses memulai penilaian dan akhirnya membuat keputusan pembelian, konsumen akan melakukan perbandingan dan penilaian terhadap produk yang akan dibeli dengan produk lain yang sejenis. Oleh karena itu, minat beli sering digunakan untuk menganalisis perilaku konsumen dalam mengevaluasi suatu produk.

Menurut Ghalandari dan Norouzi (2012), minat beli adalah probabilitas pelanggan dalam situasi tertentu saat memilih merek tertentu dari sebuah kategori produk. Jadi minat beli adalah kesungguhan hati untuk memiliki sesuatu dengan pengorbanan dimana minat beli itu timbul karena konsumen merasa puas terhadap kualitas produk yang diberikan oleh perusahaan dan minat beli ini akan dipengaruhi oleh pengetahuan konsumen terhadap merek dari sebuah kategori produk yang ditawarkan oleh produsen yang dianggap dapat memenuhi kebutuhannya. Para pemasar perlu mengidentifikasi keadaan yang memicu kebutuhan tertentu, dengan mengumpulkan informasi dari sejumlah konsumen. Mereka kemudian dapat menyusun strategi pemasaran yang mampu memicu minat beli konsumen. Ini sangat penting pada pembelian suatu produk yang memerlukan beberapa informasi yang lebih, misalnya pada barang-barang mewah, paket liburan, makanan mahal, dll.

Sedangkan menurut Kristina (2013) Intention to buy atau minat beli juga didefinisikan sebagai pernyataan yang berkaitan dengan batin yang mencerminkan rencana dari pembeli untuk membeli suatu merek tertentu dalam suatu periode waktu tertentu. Dapat dikatakan bahwa minat beli merupakan pernyataan mental dari konsumen yang mecerminkan rencana pembelian sejumlah produk dengan merek tertentu. Hal ini sangat diperlukan oleh para pemasar untuk mengetahui minat beli konsumen terhadap suatu produk, baik para pemasar maupun ahli ekonomi menggunakan variabel minat beli untuk memprediksi perilaku konsumen dimasa yang akan datang. Selain itu, Ghalandari dan Norouzi (2012) mengatakan bahwa minat beli dapat membantu manajer dalam pengambilan keputusan pemasaran mereka terkait dengan permintaan produk, menentukan segmentasi pasar dan untuk penentuan strategi promosi. Peneliti lain, Kuntjara (2007), menguatkan bahwa salah satu indikator sukses atau tidaknya produk dalam suatu perusahaan di pasar adalah seberapa jauh tumbuhnya minat beli konsumen terhadap produk tersebut.

\section{Prediktor Minat Beli Smartphone Blackberry}

Country of Origin. Country of Origin atau negara asal dari suatu produk merupakan elemen dari pemasaran yang penting untuk diketahui, karena $\mathrm{COO}$ dapat mempengaruhi persepsi konsumen dan perilaku konsumen saat akan melakukan pembelian. Negara asal produk atau Country of Origin adalah unsur ekstrinsik suatu produk yang hampir sama dengan brand atau merek. Selain itu, Informasi negara asal juga berfungsi untuk memandu konsumen dalam 
mengevaluasi merek atau produk yang mereka pilih (Ghalandari dan Norouzi, 2012). Jadi, negara asal atau country of origin adalah unsur terpenting dari suatu produk disamping pengetahuan konsumen tentang nama merek. Informasi negara asal ini nantinya juga akan mempengaruhi persepsi konsumen tentang kualitas produk yang akan mereka beli dan informasi negara asal dapat membimbing konsumen untuk mengevaluasi merek atau produk sebelum mereka melakukan pembelian.

Dalam proses pembelian, konsumen tidak hanya berpikir tentang kualitas dan harga produk yang ditawarkan oleh perusahaan akan tetapi mereka juga akan mempertimbangkan merek dan negara asal atau COO. Beberapa konsumen telah menggunakan informasi $\mathrm{COO}$ untuk menilai suatu produk, sebagai contoh, elektronik buatan dari negara Jepang dapat diandalkan. Beberapa konsumen percaya bahwa label Made in pada suatu produk dapat merangsang minat beli mereka terhadap suatu produk, namun tinggi rendahnya kualitas suatu produk tergantung pada persepsi mereka terhadap suatu negara. Pendapat ini diutarakan oleh Yasin et.al. (2007).

Penelitian yang dilakukan oleh Rouhani dan Hanzaee (2011), menemukan adanya pengaruh positif dan signifikan antara negara asal terhadap minat beli konsumen pada pembelian mobil-mobil mewah. Selanjutnya penelitian Kristina (2013) terhadap minat beli mobil Honda Jazz menemukan bahwa country of origin berpengaruh secara positif dan signifikan terhadap minat beli konsumen. Dua penelitian yang dilakukan oleh Ghalandari dan Norouzi (2012) serta Lin dan Chen (2006) menemukan bahwa citra negara asal, pengetahuan tentang produk dan pengembangan terhadap produk secara signifikan dan positif berpengaruh terhadap minat beli konsumen. Sedangkan penelitian yang dilakukan Chao dan Rajendran (1993) serta Lee dan Lee (2009) menemukan bahwa negara asal atau Country of origin mempengaruhi minat beli konsumen terhadap suatu produk, artinya semakin banyak pengetahuan konsumen tentang suatu negara dan semakin baik citra negara asal produk maka semakin tinggi pula minat belinya.

Berdasarkan penjelasan diatas, maka hipotesa yang digunakan adalah:

\section{H1 : Country of origin memiliki pengaruh positif terhadap minat beli konsumen.}

Luxury Brand Perception. Luxury Brand Perception atau persepsi merek mewah adalah produk dan jasa yang tidak dianggap penting dan berkaitan dengan kemakmuran. Konsep mewah telah hadir dalam berbagai bentuk sejak awal. Luxury Brand telah berkembang dengan cepat dalam beberapa tahun terakhir. Hal ini merupakan pasar yang menarik bagi perusahaan-perusahaan asing. Sebagai contoh, harga smartphone mewah seperti Apple, Samsung, Sony, Blackberry, windows phone bisa sekitar dua atau tiga kali harga aslinya 
dari perusahaan. Aaker dalam Rouhani dan Hanzaee (2011) menyimpulkan bahwa konsumen dapat mengaitkan produk mewah dengan merek yang memiliki kualitas unggul dan memiliki jaminan sehingga mereka merasakan nilai lebih dari produk atau merek yang mereka beli. Selain itu, kualitas yang tinggi dipandang sebagai karakter dasar dari sebuah produk mewah.

Groth dan McDaniel (1993) mendukung asumsi bahwa persepsi eksklusif atau unik dari sebuah merek adalah juga terkait dengan biaya. Merek eksklusif adalah posisi dari merek yang sedemikian rupa sehingga terdapat harga yang relatif tinggi terhadap produk sejenis. Menurut Rouhani dan Hanzaee (2011) produk mewah adalah tanda status dan kelas dalam masyarakat modern. Dua alasan yang dijadikan konsumen dalam membeli barang-barang mewah adalah untuk menunjukkan bahwa mereka berasal dari kelas yang lebih tinggi dan untuk membedakan diri dari orang-orang dari kelas bawah. Penelitian Nia and Zaichkowsky (2000), memberikan hasil bahwa konsumen percaya bahwa kepemilikan asli produk dengan merek mewah memberi mereka kepuasan pribadi dan membantu mereka dikagumi, diakui, dan diterima oleh orang lain.

Menyimak pembahasan di atas, maka hipotesis dari penelitian ini adalah:

$\mathrm{H} 2$ : Country of origin memiliki pengaruh positif terhadap Luxury brand perception

H3 : Luxury brand perception memiliki pengaruh positif terhadap minat beli konsumen.

Brand Preference. Brand Preference atau Preferensi merek merupakan salah satu bentuk apresiasi konsumen terhadap merek dan menjadi penting karena merupakan tahapan yang dilalui untuk menuju loyalitas merek (Kotler, 2003). Rouhani dan Hanzaee (2011) mengatakan bahwa kelompok referensi berpengaruh pada pengambilan keputusan pembelian produk maupun merek. Dengan kata lain, konsumen akan melakukan keputusan pembelian apabila merek tersebut dapat mengambarkan mutu/kualitas dari suatu produk, kemudian konsumen akan senang terhadap merek tersebut, akhirnya konsumen akan loyal terdahap merek tersebut. Selain itu, pendapat atau pengalaman pribadi/ pengalaman orang lain yang sudah menggunakan produk tertentu juga dapat mempengaruhi seorang konsumen dalam mengevaluasi produk atau merek yang akan mereka beli. Dari penjelasan di atas, maka hipotesis yang digunakan adalah :

H4 : Brand preference memiliki pengaruh positif terhadap minat beli konsumen 
Kerangka Penelitian

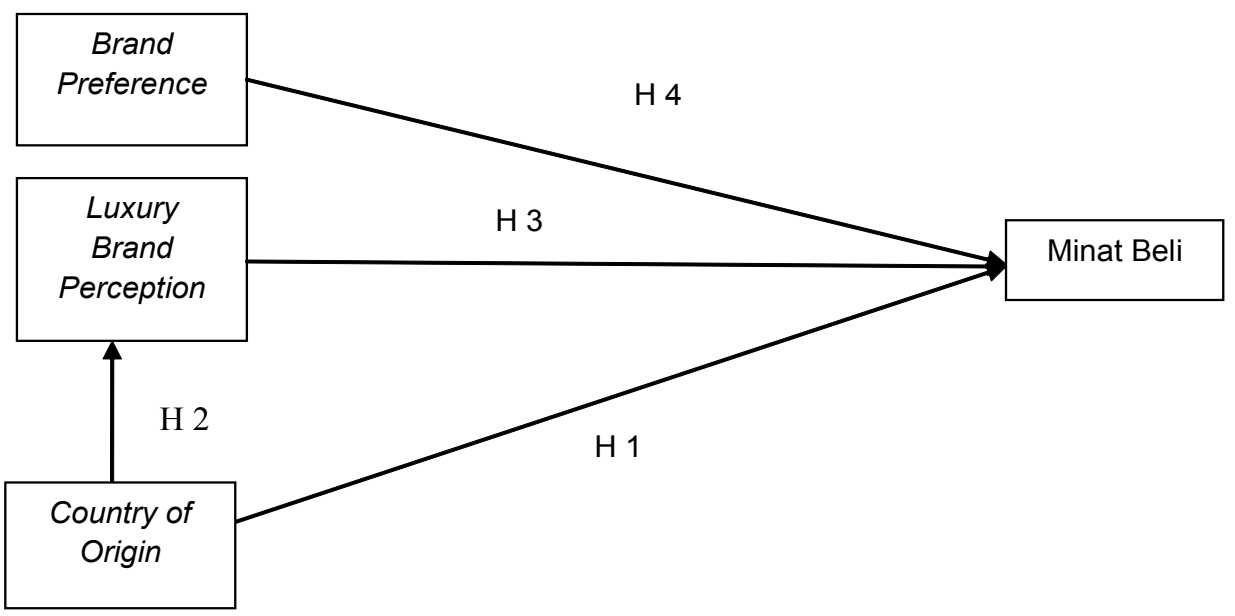

Gambar 1: Kerangka Penelitian

\section{METODE PENELITIAN}

Lokasi dari penelitian ini adalah Universitas Islam Indonesia Yogyakarta, dengan populasinya adalah mahasiswa Fakultas Ekonomi, Universitas Islam Indonesia yang menggunakan Smartphone Blackberry. Sampel di ambil dengan menggunakan teknik convienience sampling technique sebanyak 250. Karena penelitian ini meggunakan teknik analisis Structural Equation Modeling (SEM) yang membutuhkan minimal 100-200 responden (Ferdinand, 2006), peneliti membuat 50 kuesioner lebih dari jumlah minimum dikarenakan untuk mengatisipasi kuesioner yang tidak dijawab dengan baik oleh responden dan apabila kuesioner tersebut tidak dikembalikan kepada peneliti. 
Tabel 1. Definisi Operasional Variabel

Variabel, pengertian, dan indikator

Brand preference atau preferensi merek adalah keadaan dimana konsumen menyukai merek karena merek tersebut menyenangkan. Ketertarikan terhadap merek

Ketertarikan untuk mencoba

Kecenderungan beralih produk di masa yang akan datang

Luxury brand perception atau persepsi merek mewah adalah persepsi konsumen mengenai suatu produk yang berkaitan dengan kualitas produk dan tingkat kemakmuran dari konsumen serta sejauh mana suatu produk dapat memberikan jaminan kepada konsumennya.

Persepsi merek mewah mengenai dimensi keuangan

Persepsi merek mewah mengenai dimensi sosial

Persepsi merek mewah mengenai dimensi individu

Persepsi merek mewah mengenai dimensi kenikmatan

Negara asal dikenal untuk memandu asosiasi merek atau segala hal yang berkaitan dengan ingatan mengenai merek di benak konsumen.

Smartphone yang digunakan memiliki kualitas yang baik

Smartphone yang digunakan dikerjakan di negara yang maju

Smartphone yang digunakan dikerjakan di negara yang memiliki reputasi yang baik

Teknologi yang digunakan negara tersebut sudah canggih untuk menciptakan smartphone Blackberry

Desain produk dari smartphone sesuai dengan perkembangan zaman dan mengikuti keinginan konsumen.

Minat beli adalah probabilitas bahwa pelanggan dalam situasi tertentu saat memilih merek tertentu dari sebuah kategori produk. Minat transaksional, yaitu kecenderungan seseorang untuk membeli produk.

Minat referensial, yaitu kecenderungan seseorang untuk mereferensikan produk kepada orang lain.

Minat preferensial, yaitu minat yang menggambarkan perilaku seseorang yang memiliki prefrensi utama pada produk tersebut.

Minat eksploratif, minat ini menggambarkan perilaku seseorang yang selalu mencari informasi mengenai produk yang diminatinya dan mencari informasi untuk mendukung sifat-sifat positif dari produk tersebut.
Lau dan Lee (2000) dalam Kristina (2013), P. K. Hellier, G. M. Geursen, R. A. Carr \& J. A. Rickard, 2003 dalam Johanna (2006)

\section{Rouhani dan}

Hanzaee (2011),

Wiedmann,Hennigs,

Siebels (2007)

Ghalandari dan

Norouzi, (2012), Kotler

(1993); Laroche et al., Jenes (2005) dan

Yassin et al (2007)

dalam Listiana (2012)

Crosno et.al., dalam

Ghalandari dan Norouzi

(2012), Ferdinand

(2002)

Setiap butir pertanyaan yang ada pada masing-masing indikator pada variabel di atas telah disediakan tanggapan secara tertutup dengan skala 5 Likert, dimana mulai dari skor 1 menunjukkan sangat tidak setuju sampai dengan skor 5 menunjukkan sangat setuju.

Jenis data yang digunakan adalah data primer yaitu data yang diperoleh secara langsung dari subyek penelitian dengan menggunakan alat pengambilan data secara langsung sebagai sumber informasi yang dicari. Penelitian ini, 
dilakukan dengan menyebarkan kuesioner yang berisi tentang pertanyaan dan pernyataan yang sesuai tentang brand preference, luxury brand perception, country of origin dan minat beli. Pada kuesioner tersebut menggunakan lima skala Likert, dimana 1 menunjukkan Sangat Tidak Setuju dan 5 menunjukkan Sangat Setuju.

Sebelum digunakan untuk perhitungan dan analisis penelitian, maka data yang diperoleh seperti yang telah dijelaskan pada definisi operasional di atas perlu dilakukan pengujian kualitas data terlebih dahulu, dengan uji validitas dan reliabilitas data. Uji validitas diuji dengan korelasi product moment Pearson dan reliabilitas diuji dengan metode Cronbach Alpha. Indikator dan variabel yang berhasil lolos dari uji kualitas data selanjutnya dianalisis dengan menggunakan Structural Equation Modelling (SEM) AMOS versi 21. Alat analisis tersebut sekaligus digunakan untuk membuktikan hipotesis-hipotesis yang telah ditetapkan sebelumnya dan untuk menganalisis hubungan kausalitas dalam model struktural yang diusulkan.

\section{HASIL PENELITIAN}

Dari 250 kuesioner yang disebar ke responden, ternyata peminat smarthphone Blackberry tertinggi adalah wanita dengan jumlah 134 orang atau sebesar $53,6 \%$ sedangkan sisanya adalah pria dengan jumlah 116 orang atau sebesar $46,4 \%$. Umur antara 18-23 tahun adalah yang paling tinggi dengan $65,6 \%$, dengan Uang saku perbulan antara Rp 1.000.000-Rp 2.000.000 sebanyak $35,2 \%$ dan pengeluaran perbulan sebesar Rp 500.000-Rp 1.499.999 sebanyak $34,4 \%$. Profil karakteristik responden akan disajikan pada Tabel 2.

Tabel 2. Karakteristik Responden

\begin{tabular}{|c|c|c|c|c|}
\hline No & Karakteristik & Keterangan & $\begin{array}{c}\text { Jumlah } \\
\text { Responden }\end{array}$ & Presentase \\
\hline 1 & Jenis Kelamin & $\begin{array}{l}\text { Pria } \\
\text { Wanita }\end{array}$ & $\begin{array}{l}116 \\
134\end{array}$ & $\begin{array}{c}46,4 \% \\
53,6 \%\end{array}$ \\
\hline 2 & Usia & $\begin{array}{l}<18 \text { tahun } \\
18-23 \text { tahun } \\
>23 \text { tahun }\end{array}$ & $\begin{array}{c}33 \\
164 \\
53\end{array}$ & $\begin{array}{l}13,2 \% \\
65,6 \% \\
21,2 \%\end{array}$ \\
\hline 3 & Uang Saku & $\begin{array}{l}<\operatorname{Rp} 1.000 .000 \\
\operatorname{Rp} 1.000 .000-\operatorname{Rp} .2 .000 .000 \\
\operatorname{Rp} 2.000 .001-\operatorname{Rp} .3 .000 .000 \\
\operatorname{Rp} 3.000 .001-\operatorname{Rp} .4 .000 .000 \\
>\operatorname{Rp} 4.000 .000\end{array}$ & $\begin{array}{c}70 \\
88 \\
20 \\
67 \\
5\end{array}$ & $\begin{array}{c}28,0 \% \\
35,2 \% \\
8.0 \% \\
26,8 \% \\
2.0 \%\end{array}$ \\
\hline 4 & Pengeluaran & $\begin{array}{l}<\operatorname{Rp} 500.000 \\
\operatorname{Rp} 500.000-\text { Rp.1.499.999 } \\
\operatorname{Rp} 1.500 .000 \text { - Rp. } 2.499 .999 \\
\operatorname{Rp} 2.500 .000 \text { - Rp. } 3.499 .999 \\
>\operatorname{Rp} 3.500 .000\end{array}$ & $\begin{array}{c}81 \\
86 \\
11 \\
67 \\
5\end{array}$ & $\begin{array}{c}32,4 \% \\
34,4 \% \\
4,4 \% \\
26,8 \% \\
2,0 \%\end{array}$ \\
\hline
\end{tabular}


Pada Tabel 2 menunjukkan bahwa mayoritas pengguna smartphone Blackberry adalah wanita yang berusia muda yaitu usia antara 18-23 tahun dan memiliki uang saku yang cukup, sedangkan mayoritas pengeluaran dari responden masih relatif tinggi karena smartphone Blackberry saat ini harganya masih relatif tinggi.

Selanjutnya, agar memenuhi kriteria data yang berkualitas untuk dijadikan sebagai dasar analisis, maka data pada setiap indikator perlu dilakukan pengujian validitas (kesahihan data) dan reliabilitas (kehandalan data) pada 100 orang responden terlebih dahulu. Validitas diuji melalui uji korelasi product moment Pearson. Suatu indikator dianggap valid jika rhitung > rtabel dan bernilai positif maka indikator tersebut dapat dikatakan valid (Ghozali, 2005). $r$ hitung pada a $5 \%$ dan derajat kebebasan sebesar 98 , maka $r$ tabel sebesar 0.196 . Sementara reliabilitas adalah alat untuk mengukur suatu kuesioner yang merupakan indikator dari variabel atau konstruk. Suatu kuesioner dikatakan reliabel atau handal jika jawaban seseorang terhadap pertanyaan adalah konsisten atau stabil dari waktu ke waktu. Adapun cara yang digunakan untuk menguji reliabilitas kuesioner dalam penelitian ini adalah menggunakan rumus koefisien Cronbach Alpha, yaitu apabila nilai $\geq 0.60$ maka kuesioner tersebut reliable (Ghozali, 2005).

Tabel 3. Hasil Uji Validitas dan Reliabitas Data

\begin{tabular}{|c|c|c|c|}
\hline Butir Indikator & $\begin{array}{l}\text { Validitas } \\
\text { (rh) }\end{array}$ & Reliabilitas & $\begin{array}{l}\text { Rata- } \\
\text { rata }\end{array}$ \\
\hline Brand Preference & & 0.720 & 3.31 \\
\hline Tertarik dengan smartphone Blackberry & 0.784 & & 3.29 \\
\hline Tertarik untuk mencoba smartphone Blackberry & 0.790 & & 3.28 \\
\hline Cenderung akan beralih produk di masa yang akan datang & 0.836 & & 3.37 \\
\hline Luxury Brand Perception & & 0.844 & 3.58 \\
\hline $\begin{array}{l}\text { Menggunakan smartphone Blackberry karena banyak uang } \\
\text { Menggunakan smartphone Blackberry karena pergaulan } \\
\text { sosial }\end{array}$ & 0.743 & & $\begin{array}{l}3.57 \\
3.65\end{array}$ \\
\hline Menggunakan smartphone Blackberry karena butuh & 0.892 & & 3.60 \\
\hline Menggunakan smartphone Blackberry karena memuaskan & 0.851 & & 3.50 \\
\hline Country of Origin & & 0.887 & 3.54 \\
\hline $\begin{array}{l}\text { Smartphone Blackberry yang dihasilkan oleh negara Kanada } \\
\text { memiliki kualitas yang baik }\end{array}$ & 0.821 & & 3.55 \\
\hline $\begin{array}{l}\text { Smartphone Blackberry yang dihasilkan oleh negara Kanada } \\
\text { dikerjakan di negara yang maju }\end{array}$ & 0.898 & & 3.60 \\
\hline $\begin{array}{l}\text { Smartphone Blackberry yang dihasilkan oleh negara Kanada } \\
\text { memiliki reputasi yang baik }\end{array}$ & 0.820 & & 3.58 \\
\hline $\begin{array}{l}\text { Teknologi yang digunakan oleh negara Kanada untuk } \\
\text { menciptakan smartphone Blackberry sudah canggih }\end{array}$ & & & 3.50 \\
\hline
\end{tabular}




\begin{tabular}{lccc}
\hline \multicolumn{1}{c}{ Butir Indikator } & $\begin{array}{c}\text { Validitas } \\
\text { (rh) }\end{array}$ & $\begin{array}{c}\text { Reliabilitas } \\
\begin{array}{l}\text { Desain smartphone yang dihasilkan oleh negara Kanada } \\
\text { mengikuti perkembangan zaman dan keinginan konsumen }\end{array}\end{array}$ & $\begin{array}{c}\text { Rata- } \\
\text { rata }\end{array}$ \\
$\begin{array}{l}\text { Minat Beli } \\
\text { Akan membeli smartphone Blackberry }\end{array}$ & 0.803 & 3.50 \\
$\begin{array}{l}\text { Akan merekomendasikan smartphone Blackberry kepada } \\
\text { orang lain }\end{array}$ & 0.730 & & 3.58 \\
$\begin{array}{l}\text { Smartphone pertama yang akan dibeli adalah Blackberry } \\
\text { Selalu mencari informasi mengenai smartphone Blackberry }\end{array}$ & 0.753 & 3.46 \\
\hline
\end{tabular}

Sumber : Data primer diolah, 2014

Dari Tabel 3 dapat diketahui besarnya koefisien korelasi dari seluruh butir pertanyaan mempunyai nilai $r$ hitung lebih besar dari 0,196. Dengan demikian dapat disimpulkan bahwa seluruh butir dinyatakan valid. Artinya, seluruh butir pertanyaan yang ada pada instrumen penelitian dapat dinyatakan layak sebagai instrumen untuk mengukur data penelitian. Hasil yang sama diperoleh pada perhitungan reliabiltas. Perhitungan reliabilitas menunjukkan hasil Cronbach's Alpha lebih besar dari 0.60 . Dengan demikian seluruh butir pertanyaan yang tertuang dalam kuesioner penelitian ini dapat dinyatakan handal/reliabel. Artinya, kuesioner ini memiliki hasil yang konsisten jika dilakukan pengukuran dalam waktu dan model atau desain yang berbeda.

Di samping itu tabel 3 menunjukkan hasil perhitungan rata-rata nilai tanggapan responden pada masing-masing indikator dan variabel penelitian. Berdasarkan pada skala 1 (satu) sampai dengan 5 (lima) dan dibagi dalam 5 rangking penilaian, maka dikatakan bahwa dengan skor rata-rata penilaian responden sebesar 3.31 (interval 2.61-3.40) pada variabel brand preference adalah termasuk pada kriteria cukup setuju. Sementara itu, penilaian tertinggi pada indikator cenderung akan beralih produk di masa yang akan datang yaitu dengan rata - rata sebesar 3,37 (cukup setuju) dan penilaian terendah pada indikator tertarik untuk mencoba smartphone Blackberry.

Rata - rata penilaian responden terhadap variabel luxury brand perception adalah sebesar 3,58 (setuju). Hal ini berarti konsumen telah memberikan penilaian yang setuju terhadap variabel luxury brand perception. Penilaian tertinggi pada indikator menggunakan smartphone Blackberry karena pergaulan sosial yaitu dengan rata - rata sebesar 3,65 (setuju) dan penilain terendah pada indikator menggunakan smartphone Blackberry karena memuaskan.

Rata - rata penilaian responden terhadap variabel country of origin adalah sebesar 3,54 (setuju). Hal ini berarti konsumen telah memberikan penilaian yang setuju terhadap variabel country of origin. Penilaian tertinggi pada indikator negara asal yaitu Kanada adalah negara maju yaitu dengan rata - rata sebesar 3,60 
(setuju) dan penilain terendah pada indikator teknologi dan desain smartphone di negara Kanada yang sudah canggih dan mengikuti perkembangan zaman.

Terakhir, skor rata - rata penilaian responden terhadap variabel minat beli adalah sebesar 3,58 (setuju). Hal ini berarti konsumen telah memberikan penilaian yang setuju terhadap variabel minat beli. Penilaian tertinggi pada indikator selalu mencari informasi menggenai smartphone Blackberry dengan rata - rata sebesar 3,72 (setuju) dan penilain terendah pada indikator akan membeli smartphone Blackberry diwaktu yang akan datang.

\section{Pengukuruan Overall Goodness-of-Fit}

Tahapan pada analisis berikutnya adalah menilai goodnees-of-fit (uji kesesuaian model). Dalam SEM tidak ada alat uji statistik tunggal untuk mengukur atau menguji hipotesis. Peneliti dapat melakukan pengujian dengan menggunakan beberapa goodness-of-fit indeks untuk mengukur baik tidaknya atau "kebenaran" model yang diajukan (Hair dkk, 1998) dalam Ferdinand (2006). Pada langkah ini kesesuaian model mulai dievaluasi, melalui telaah terhadap berbagai kriteria goodness-of-fit. Hasil pengukuran overall goodness-of-fit (uji kesesuaian model) penelitian ini disajikan pada Tabel 4.

Tabel 4. Hasil Goodness of Fit Index

\begin{tabular}{lccc}
\hline \multicolumn{1}{c}{ Goodness of-Fit } & Cut off Value & $\begin{array}{c}\text { Hasil Kesesuaian } \\
\text { Model }\end{array}$ & Keterangan \\
\hline X 2- Chi Square Statistic & Diharapkan kecil & 131.933 & Baik \\
Significance Probability & $\geq 0.05$ & 0.059 & Baik \\
RMSEA & $\leq 0,08$ & 0.051 & Baik \\
GFI & $\geq 0,90$ & 0.927 & Baik \\
CMIN/DF & $\leq 2,00$ & 1.232 & Baik \\
AGFI & $\geq 0,90$ & 0.900 & Baik \\
TLI & $\geq 0,95$ & 0.958 & Baik \\
CFI & $\geq 0,95$ & 0.965 & Baik \\
\hline
\end{tabular}

Sumber: Data Primer yang Diolah 2014

Berdasarkan hasil uji goodness of fit menunujukkan bahwa nilai probabilitas Chi Square 0,059 $\geq 0,05$, CMIN/DF $=1,232 \leq 2$; RMSEA $\leq$ nilai kritisnya $=0,08$, GFI dan AGFI $\geq 0,90$, TLI dan CFI $\geq 0,95$. Hal ini berarti model persamaan struktural dalam penelitian ini adalah fit (memiliki kesesuaian), dengan demikian dapat disimpulkan bahwa model pada penelitian ini baik dan dapat dilakukan analisis terhadapnya.

\section{Pengujian Hipotesis}

Setelah melakukan uji kesesuain model, langkah selanjutnya adalah melakukan uji hipotesis, uji hipotesis diolah dengan menggunakan program 
AMOS versi 21. Hipotesis yang dirumuskan dalam penelitian ini terdiri dari 4 hipotesis. Untuk mengetahui apakah hipotesis didukung oleh data atau tidak, maka nilai probabilitas dari Critical Ratio (C.R) dibandingkan dengan $\alpha=5 \%$. Apabila Standardized Koefisien parameter memiliki nilai probabilitas dari Critical Ratio (C.R) kurang dari $\alpha=5 \%$, maka dapat disimpulkan bahwa hipotesis penelitian didukung oleh data (terbukti secara signifikan).

Hasil pengujian terhadap model penelitian dapat digambarkansebagai berikut:

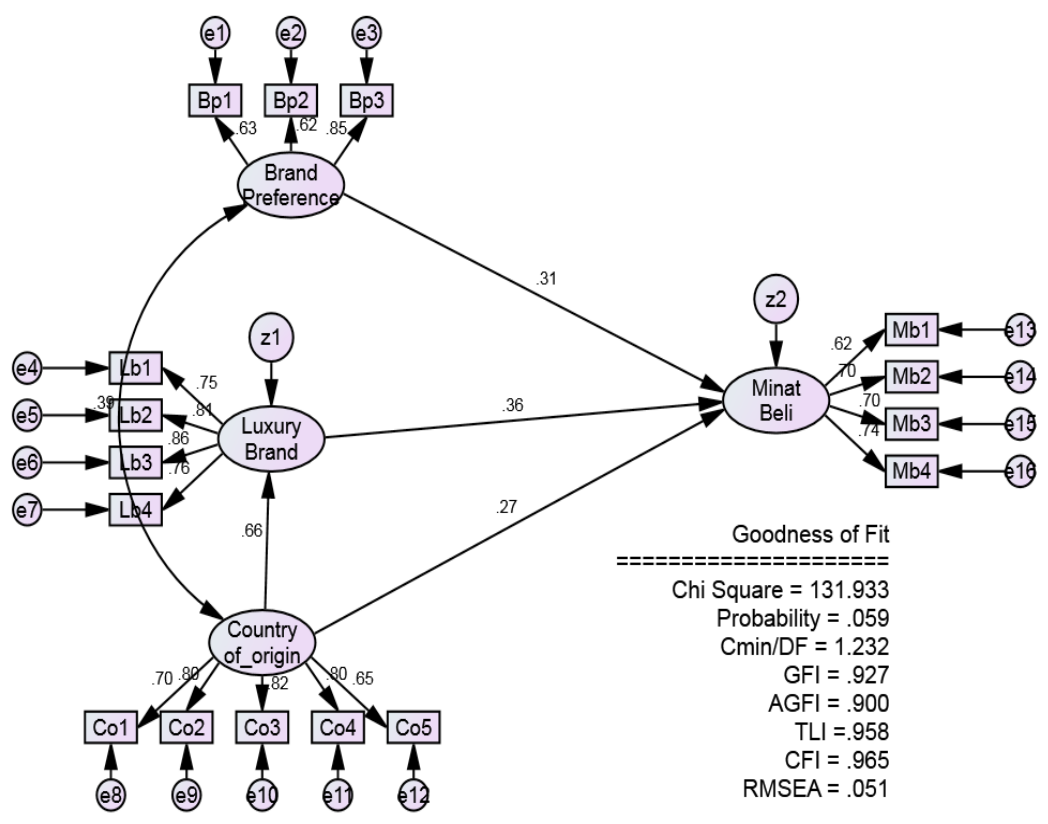

Gambar 2: hasil model penelitian

Berdasarkan analisis statistik dengan menggunakan program AMOS versi 21 , diperoleh hasil uji hipotesis yang merupakan uji hubungan kausalitas dari masing-masing variabel penelitian sebagaimana disajikan pada Tabel 5 . 
Tabel 5. Hasil Estimasi Dengan Model AMOS

\begin{tabular}{lccccc}
\hline \multicolumn{2}{c}{ Pengaruh Antar Variabel } & $\begin{array}{c}\text { Koefisien } \\
\text { Standardized }\end{array}$ & $\begin{array}{c}\text { Critical } \\
\text { Ratio }\end{array}$ & $\begin{array}{c}\text { Nilai } \\
\text { Probabilitas }\end{array}$ & Keterangan \\
\hline Luxury Brand & <--- Country of origin & 0.659 & 7.758 & 0.000 & H2 didukung \\
Minat Beli $\quad$ <-- Brand Preference & 0.311 & 3.947 & 0.000 & H4 didukung \\
Minat Beli $\quad$ <-- Luxury Brand & 0.362 & 3.909 & 0.000 & H3 didukung \\
Minat Beli $\quad$ <-- Country of origin & 0.269 & 2.791 & 0.005 & H1 didukung \\
\hline
\end{tabular}

Sumber: Data Primer yang Diolah, 2014

Berdasarkan Tabel 5 dapat ditulis persamaan:

$$
\mathrm{MB}=0,311 \mathrm{BP}+0,362 \mathrm{LB}+0,269 \mathrm{CO}
$$

$\mathrm{LB}=0,659 \mathrm{CO}$

Berdasarkan Tabel 5, Hipotesis pertama dalam penelitian ini menyatakan bahwa "H1: Country of origin memiliki pengaruh positif terhadap minat beli konsumen". Uji signifikansi terhadap hipotesis 1 terbukti secara signifikan karena pengaruh country of origin terhadap minat beli diperoleh koefisien standardized sebesar 0,269 dan probabilitas sebesar 0,005<0,05 yang berarti signifikan pada taraf signifikansi $5 \%$ ( $\mathrm{H} 1$ didukung). Hasil estimasi pengaruh country of origin terhadap minat beli diperoleh koefisien jalur (standardized regression weight estimate) $=0.269$, Artinya pengaruh antara variabel country of origin terhadap minat beli adalah positif. Artinya semakin tinggi persepsi dan pengetahuan tentang country of origin pada produk smartphone Blackberry maka akan semakin tinggi minat beli konsumen.

Hipotesis kedua dalam penelitian ini menyatakan bahwa "H2 : Country of origin memiliki pengaruh positif terhadap Luxury brand perception". Uji signifikansi terhadap hipotesis 2 terbukti secara signifikan, karena diperoleh nilai probabilitas 0,000 atau lebih kecil dari 0,05 yang berarti signifikan pada taraf signifikansi $5 \%$ ( $\mathrm{H} 2$ didukung). Hasil estimasi pengaruh country of origin terhadap luxury brand perception diperoleh koefisien jalur (standardized regression weight estimate) $=0.659$, artinya pengaruh antara variabel country of origin terhadap luxury brand perception adalah positif. Artinya semakin baik presepi dan semakin tinggi pengetahuan tentang country of origin pada produk smartphone Blackberry semakin tinggi pula luxury brand perception konsumen.

Hipotesis ketiga dalam penelitian ini menyatakan bahwa "H3: Luxury brand perception memiliki pengaruh positif terhadap minat beli konsumen". Uji signifikansi terhadap hipotesis 3 terbukti secara signifikan, karena diperoleh nilai probabilitas 0,000 atau lebih kecil dari 0,05 yang berarti signifikan pada taraf signifikansi 5\% (H3 didukung). Hasil estimasi pengaruh luxury brand perception terhadap minat beli diperoleh koefisien jalur (standardized regression weight estimate) $=0.362$, artinya pengaruh antara variabel luxury brand perception terhadap minat beli adalah positif. Semakin tinggi luxury brand perception pada smartphone Blackberry maka semakin tinggi pula minat beli konsumen. 
Hipotesis keempat dalam penelitian ini menyatakan bahwa ":H4: Brand preference memiliki pengaruh positif terhadap minat beli konsumen”. Uji signifikansi terhadap hipotesis 4 terbukti secara signifikan, karena diperoleh nilai probabilitas 0,000 atau lebih kecil dari 0,05 yang berarti signifikan pada taraf signifikansi 5\% (H4 didukung). Hasil estimasi pengaruh brand preference terhadap minat beli diperoleh koefisien jalur (standardized regression weight estimate) $=0.311$, artinya pengaruh antara variabel brand preference terhadap minat beli adalah positif. Semakin tinggi brand preference pada produk dan semakin konsumen menyukai merek smartphone Blackberry maka semakin tinggi pula minat belinya.

\section{PEMBAHASAN}

Penelitian ini telah berhasil mengungkap hipotesis/dugaan sebelumnya tentang pengaruh positif brand preference, luxury brand perception dan Country of origin terhadap minat beli konsumen, serta pengaruh positif country of origin terhadap luxury brand perception. Hal ini dibuktikan dengan terpenuhinya secara signifikan 4 hipotesis yang diajukan pada penelitian ini dengan menggunakan SEM AMOS versi 21.

Hasil analisis AMOS menunjukkan adanya pengaruh positif dan signifikan country of origin terhadap minat beli. Hasil penelitian ini mendukung penelitian yang dilakukan oleh Rouhani dan Hanzaee (2011), Kristina (2013), Ghalandari dan Norouzi (2012), Lin dan Chen (2006), Chao dan Rajendran (1993) serta Lee dan Lee (2009). Hasil ini dapat diartikan bahwa semakin baik persepsi konsumen dan semakin tinggi pengetahuan konsumen terhadap negara asal produk smartphone Blackberry semakin tinggi pula minat beli konsumen terhadap produk smartphone Blackberry.

Apabila dibandingkan dengan variabel lainnya, variabel country of origin perlu untuk lebih ditingkatkan lagi dalam membangun minat beli konsumen, khususnya dalam pembelian alat-alat elektronik seperti alat telekomunikasi smartphone. Hal ini mengindikasikan bahwa produsen smartphone Blackberry perlu memberikan informasi yang lebih tentang negara asal produk kepada konsumen agar konsumen lebih tertarik lagi untuk melakukan pembelian, inovasi produk bagi smartphone Blackberry sehingga mampu menciptakan produk-produk baru yang lebih canggih dan diminati oleh trend saat ini, bahkan jika perlu terus menjadi pioner merek dari smartphone.

Penelitian ini menunjukkan adanya pengaruh yang positif dan signifikan country of origin terhadap luxury brand perception. Hasil ini mendukung peneltian yang dilakukan oleh Rouhani dan Hanzaee (2011), dan Kristina (2013). Hal ini berarti semakin tinggi persepsi konsumen terhadap negara asal produk smartphone Blackberry maka semakin tinggi pula persepsi konsumen terhadap luxury brand perception pada smartphone Blackberry. Untuk meningkatkan 
pengaruh negara asal agar dapat mempengaruhi persepsi merek mewah dibenak konsumen, maka produsen smartphone Blackberry perlu menambah informasi-informasi negara asal Blackberry tersebut dibuat yaitu negara Kanada yang merupakan negara maju, lebih meningkatkan teknologi dari Blackberry, serta lebih meningkatkan desain dari Blackberry yang lebih mewah dan elegan lagi agar konsumen tertarik untuk melakukan pembelian.

Dari hasil data yang yang diolah dengan AMOS menunjukkan adanya pengaruh yang positif dan signifikan luxury brand perception terhadap minat beli konsumen. Hasil ini mendukung penelitian yang dilakukan oleh Rouhani dan Hanzaee (2011), dan Kristina (2013). Hal ini berarti semakin tinggi persepsi konsumen terhadap barang mewah pada smartphone Blackberry maka semakin tinggi minat beli pada smartphone Blackberry tersebut. Untuk membangun persepsi merek mewah dibenak konsumen, produsen dari smartphone Blackberry perlu membangun citra merek dari Blackberry dan lebih meningkatkan kualitas yang sesuai dengan harga yang ditawarkan, sehingga konsumen berminat untuk melakukan pembelian. Produsen Blackberry juga perlu untuk meningkatkan indikator luxury brand perception yang dianggap masih rendah oleh konsumen, yaitu menggunakan smartphone Blackberry karena memuaskan. Implikasinya, sebaiknya produsen memperbaiki dan meningkatkan kinerja dari produk smartphone Blackberry agar konsumen semakin puas menggunakan smartphone tersebut. Inovasi pada hardware dan software perlu ditingkatkan karena persaingan bisnis yang semakin ketat menyebabkan perusahaan harus cepat mengikuti perkembangan yang ada.

Hasil pengujian hipotesis juga menunjukkan adanya pengaruh yang positif dan signifikan brand preference terhadap minat beli konsumen. Hasil penelitian ini juga mendukung peneltian yang dilakukan oleh Rouhani dan Hanzaee (2011), dan Kristina (2013). Artinya semakin tinggi persepsi konsumen terhadap brand preference dan semakin konsumen menyukai merek suatu produk maka minat beli konsumen pada produk smartphone Blackberry akan semakin meningkat. Pada data yang diolah oleh AMOS versi 21 brand preference memberikan pengaruh positif terhadap minat beli sebesar 0.311 , hal ini mengindikasikan bahwa produsen Blackberry perlu meningkatkan variabel brand preference yaitu dengan memenuhi kebutuhan dan keinginan dari konsumen smartphone Blackberry yang mayoritas masih berusia muda, agar konsumen akhirnya senang dengan merek atau produk yang ditawarkan, sehingga apabila kebutuhan dan keinginan mereka dapat dipenuhi maka konsumen juga berminat untuk melakukan pembelian. Selain itu, produsen smartphone Blackberry sebaiknya terus meningkatkan kualitas produk yaitu dengan menawarkan smartphone dengan desain menarik sesuai keinginan responden yang mayoritas adalah anak muda, penting juga bagi Blackberry untuk meningkatkan kelengkapan aplikasi, kemudahan dan kecepatan dalam mengakses internet. 


\section{PENUTUP}

Penelitian ini telah membuktikan hipotesis-hipotesis dari penelitian yang diajukan, sekaligaus berhasil mendukung penelitian terdahulu yang telah dilakukan oleh peneliti sebelumnya. Meskipun demikian penelitian ini juga memiliki kelemahan. Pertama, dari sisi subjek penelitian yang hanya menggunakan populasi dari mahasiswa Fakultas Ekonomi Universitas Islam Indonesia yang menggunakan smartphone Blackberry. Kedepan disarankan bagi peneliti selanjutnya untuk menambahkan subjek penelitian dengan profesi yang lebih beragam, berbagai kemungkinan penambahan yang dimaksudkan agar model penelitian dapat lebih teruji.

Kedua, penelitian ini menggunakan variabel yang mempengaruhi minat beli konsumen berupa Country of Origin, Luxury Brand Perception dan Brand preference. Padahal sangat mungkin masih ada variabel lain yang mempengaruhi minat beli konsumen, seperti variabel citra merek, ekuitas merek dan lain sebagainya.

Berdasarkan hasil penelitian ini, peneliti juga menyarankan bagi manajer pemasaran smartphone Blackberry untuk meningkatkan minat beli konsumen perlu meningkatkan faktor brand preference karena masih dinilai cukup oleh konsumen. Hal ini dapat dilakukan dengan meningkatkan kualitas produk dan desain produk yang lebih menarik terutama untuk segmen terbesar smartphone yaitu kalangan usia muda. Selain itu untuk meningkatkan produk sebagai luxury brand perception perlu memantau apa yang diharapkan konsumen saat ini, sehingga produk yang ditawarkan akan sesuai dengan harapan dan kebutuhan konsumen serta kepuasan dapat dirasakan oleh konsumen. Sedangkan dalam meningkatkan country of origin dapat dilakukan dengan meningkatkan teknologi pada produk terbarunya, sehingga smartphone Blackberry tetap sebagai telepon genggam pintar seperti dalam icon Blackberry.

\section{DAFTAR PUSTAKA}

Arikunto, S. (2002). Prosedur Penelitian Suatu Pendekatan Praktek. Jakarta: Rineka Cipta.

Chao, P. and K.N. Rajendran. (1993). Consumer Profiles and Perception: Country-of-Origin Effects. International Marketing Review, 10(2), hal: 22-39.

Felix, R. (2013). Pengguna Blackberry di Indonesia Kini Mencapai 15 Juta. Diakses tanggal 20 Oktober 2013 dari http://www.chip.co.id/news/ gadgetblackberry/ 7299/pengguna blackberry di Indonesia kini mencapai 15 juta. 
Ferdinand, A. (2002). Structural Equation Modeling dalam Penelitian Manajemen (Edisi 2). Semarang: Fakultas Ekonomi UNDIP.

.(2006). Structural Equation Modeling dalam Penelitian Manajemen: Aplikasi Model-model Rumit dalam Penelitian untuk Tesis Magister dan Disertasi Doktor (Edisi 4). Semarang: Badan Penerbit UNDIP.

Ghalandari, G. and A. Norouzi (2012), The Effect of Country of Origin on Purchase Intention: The Role of Product Knowledge". Research Journal of Applied Sciences, Engineering and Technology, 4(9): 1166-1171, 2012 ISSN: 2040-7467.

Ghozali, I. (2005). Aplikasi Analisis Multivariate Dengan Program SPSS. Semarang: Badan Penerbir Universitas Diponegoro.

Groth, J. and S.W. McDaniel (1993). The Exclusive Value Principle: The Basis for Prestige Pricing. Journal of Consumer Marketing, 10: 10-16.

Hair, J. F., R.E. Anderson, R.E. Tatham, W.C. Black (1995); Multivariate Data Analysis. New York: Macmillan.

Johanna, M. 2006. Analisis Faktor-Faktor yang Mempengaruhi Minat Beli Ulang (Studi Kasus Konsumen Pada Mandala Airline - Semarang). Tesis Magister Manajemen (Dipublikasikan). Semarang: Universitas Diponegoro.

Kotler, P. (2000). Marketing Management: The Millenium Edition. New Jersey: Prentice Hall International, Inc. (2003). Manajemen Pemasaran. Jakarta : Erlangga.

Kristina, V. (2013). Pengaruh Brand Preference, Luxury Brand Percepception dan Country of Origin pada Minat Beli Mobil Honda Jazz. Skripsi Sarjana (Tidak Dipublikasikan). Yogyakarta : Fakultas Ekonomi UII.

Kuntjara. (2007). Analisis Faktor-Faktor Yang Mempengaruhi Minat Beli Ulang Konsumen. Tesis Magister Manajemen (Dipublikasikan). Semarang: Magister Manajemen Universitas Diponegoro.

Lee, J.K. and W.N. Lee. (2009), Country of Origin Effects on Consumer Product Evaluation and Purchase Intention: The Role of Objective Versus Subjective Knowledge. Journal of International Consumer Marketing, 21(2), hal: 137-151. 
Lin, L.Y. and C.S. Chen. (2006), The Influence of The Country of Origin Image, Product Knowledge and Product Involvement on Consumer Purchase Decisions: An Empirical Study of Insurance and Catering Services in Taiwan. Journal Consumer Marketing, 23(5), hal: 248-265.

Listiana, E. (2012), Pengaruh Country of origin Terhadap Perceived Quality dengan Moderasi Etnosentris Konsumen. Jurnal Administrasi Bisnis (2012), 8(1), hal: 21-47, (ISSN:0216-1249).

Nia, A. and J.L. Zaichkowsky (2000). Do Counterfeits Devalue the Ownership of Luxury Brands? Journal of Product and Brand Management, 11 (2), $67-88$

Rouhani, F.R. and K.H. Hanzaee (2011), Investigation of the Effects of Demographic Factors and Brand Perception on the Purchase Intention of Luxury Automobiles in Iranian Consumers. Journal of Basic and Applied Scientific Research, 1(12), hal: 2851-2861,(ISSN 2090-4304).

Susanti, R. dan D. Hastjarja .K. (2010). Efek dari Country of Origin dan Pengetahuan Produk pada Evaluasi Produk dan Niat Pembelian Produk Sepeda Motor. Jurnal Ekonomi Dan Kewirausahaan, 10 (1), hal: $1-10$.

Wiedmann, K.P., Hennigs, N., Siebels, A. (2007). Measuring Consumers Luxury Value Perception: A Cross-Cultural Framework. Academy of Marketing Science Review, 2007 (7), hal: 1-23.

Yasin, N.M, M.N. Noor and O. Muhamad (2007). Does Image of Country of Origin Matter to Brand Equity? Journal of Product and Brand Management, 16 (1), 38-48 
